\title{
SYNTHESIS AND CHARACTERIZATION OF GRAPHENE NANOSHEETS/MAGNESIUM COMPOSITES PROCESSED THROUGH POWDER METALLURGY
}

\author{
SINTEZA IN KARAKTERIZACIJA MAGNEZIJEVIH KOMPOZITOV, \\ OJAČANIH Z GRAFENSKIMI NANOPLASTMI, IZDELANIH \\ Z METALURGIJO PRAHOV
}

\author{
Xiaoming Du, Kaifeng Zheng, Fengguo Liu \\ Shenyang Ligong University, School of Materials Science and Engineering, Shenyang 110159, China \\ du511@163.com \\ Prejem rokopisa - received: 2017-04-12; sprejem za objavo - accepted for publication: 2017-06-28
}

doi:10.17222/mit.2017.041

\begin{abstract}
Magnesium-matrix composites reinforced with graphene nanosheets ( $\mathrm{Mg}-\mathrm{Gr}$ ) were fabricated using a combination of powder metallurgy and hot rolling. The effects of the graphene-nanosheet content on the microstructures and density of the composites were investigated. It was found that the graphene nanosheets were gradually dispersed in the magnesium matrix with an increasing ball-milling time and a uniform dispersion was achieved after $72 \mathrm{~h}$ for the composite with a graphene content of $1.0 \%$ of mass fraction. In addition, no obvious agglomeration of graphene was observed in the as-sintered and as-rolled composites with the graphene contents of up to $1.0 \%$ of mass fraction. A coordinated deformation of multilayer graphene nanosheets occurs with a deformation of the surface grains during the rolling, which may cause a significant reduction in the number of layers of the graphene nanosheets. When increasing the graphene content, the density of the $\mathrm{Mg}-\mathrm{Gr}$ composites shows an increase.
\end{abstract}

Keywords: magnesium-matrix composites, graphene nanosheets, powder metallurgy

Kompoziti s kovinsko osnovo, ki so bili ojačani z grafitnimi nanoplastmi (Mg-Gr), so izdelani s kombinacijo postopkov metalurgije prahov in metodami vročega valjanja. Raziskani so bili vpliv vsebnosti grafitnih nanosov na mikrostrukturo in gostoto kompozitov. Ugotovljeno je bilo, da se grafenske nanoplasti postopoma razpršijo v magnezijevo matriko, s povečanjem časa krogličnega mletja. Pri kompozitu z 1,0 \% utežnih odstotkov vsebnosti grafena so dobili enakomerno disperzijo po $72 \mathrm{~h}$ mletja. Pri obeh, sintranih in valjanih kompozitih niso opazili nobene očitne aglomeracije grafena do vsebnosti $1,0 \%$ utežnih odstotkov grafena. Med valjanjem je istočasno z deformacijo površinskih zrnpotekala usklajena deformacija grafesnkih nanoplasti, kar lahko povzroči znatno zmanjšanje števila grafenskih nanoplasti. Z zviševanjem vsebnosti grafena se je povečevala gostota Mg-Gr kompozitov.

Ključne besede: kovinski kompoziti, ojačani z grafenom; grafitne nanoplasti, metalurgija prahov

\section{INTRODUCTION}

Owing to a low density, high specific strength, good machinability and easy recycling, magnesium and its alloys have widespread applications in the fields of the automobile, aerospace and electronics industries. However, the usage of magnesium is limited due to its low strength and ductility, as compared to steel and aluminium. Many attempts have been made to improve the mechanical properties of magnesium by developing magnesium-base metal-matrix composites, such as $\mathrm{Y}_{2} \mathrm{O}_{3} / \mathrm{Mg}, \mathrm{Al}_{2} \mathrm{O}_{3} / \mathrm{Mg}, \mathrm{SiCp} / \mathrm{Mg}$ and $\mathrm{Ti} / \mathrm{Mg}$, during the past decades. ${ }^{1-5}$ Recently, the researchers focused on the lighter reinforcements, such as graphene and carbon nanotube $(\mathrm{CNT})$, to enhance the mechanical properties of $\mathrm{Mg}$ alloys. ${ }^{6-7}$

Graphene, a single atomic layer of $\mathrm{sp}^{2}$ hybridized carbon, has extraordinary electrical, thermal, and physical properties. The nanometric nature and high specific surface area allow a great interaction of the reinforcement phase with the matrix even in small concentrations.
The modulus of elasticity and intrinsic fracture strength of monolayer graphene are $1 \mathrm{TPa}$ and $125 \mathrm{GPa}$, respectively. ${ }^{8-10}$ Compared to one-dimensional carbon nanotubes, two-dimensional graphene is much easier to be controlled and dispersed in a metal matrix. Furthermore, graphene can be prepared in large quantities using chemical exfoliation of graphite. ${ }^{11}$ Therefore, graphene is considered as an ideal reinforcement for metal-matrix composites.

In the past few years, research results for nanoscale graphene-reinforced polymer ${ }^{12}$ and ceramic $^{13}$ matrix composites were reported. The tensile strength of polyvinyl alcohol (PVA) filled with $0.7 \%$ mass fraction of graphene nanosheets increased by $76 \% .^{12}$ The bending strength and breaking strength of an $\mathrm{Al}_{2} \mathrm{O}_{3}$ ceramic matrix filled with $0.78 \%$ of volume fraction of graphene nanosheets increased by $30.75 \%$ and $27.20 \%$, respectively. ${ }^{13}$ However, the $\mathrm{Mg}$ composites reinforced with graphene nanosheets are relatively limited. The existing results in the literature indicate that graphene has incomparable advantages in solving the dispersion and wettabi- 


\section{M. DU et al.: SYNTHESIS AND CHARACTERIZATION OF GRAPHENE NANOSHEETS/MAGNESIUM COMPOSITES ...}

lity conundrums, compared with carbon nanotubes. There is an obvious reinforcement effect and graphene has potential applications as the ideal reinforcement in graphene-reinforced magnesium-matrix composites. ${ }^{14-16}$

In this study, graphene-nanosheet-reinforced magnesium-matrix composites ( $\mathrm{Mg}-\mathrm{Gr}$ ) were fabricated using high-energy ball milling, hot-press sintering and hot rolling. The effects of the ball-milling time on the morphologies and structures of the graphene nanosheets in the composites were studied. Meanwhile, the effects of the graphene nanosheets on the microstructure and density of the composites were also investigated.

\section{EXPERIMENTAL PART}

The graphene nanosheets used in our experiments were prepared with a modified Hummers method as reported previously. ${ }^{17}$ The experimental material was natural graphite with a particle size of about $45 \mathrm{um}$. Natural graphite was reduced at $95{ }^{\circ} \mathrm{C}$ for $24 \mathrm{~h}$ using hydrazine hydrate. Graphene nanosheets with a thickness of several atomic layers were obtained. The preparation method was similar to that from reference ${ }^{17}$. A magnesium powder with a $99.5 \%$ purity was bought from Hebi Jianglang Metals Co., Ltd., China, with the average particle size of $20 \mathrm{um}$ and it was used as the matrix material. The densities of magnesium powder and graphene nanosheets were $1.74 \mathrm{~g} / \mathrm{cm}^{3}$ and $2.25 \mathrm{~g} / \mathrm{cm}^{3}$, respectively.

Pure magnesium powders were initially mixed with $(0.5,1.0,1.5,2.0) \%$ of mass fractions of the as-prepared graphene nanosheets in a conventional rotating ballmilling machine using a stainless jar and balls. Ball milling was carried out in an argon atmosphere at a rotating speed of $90 \mathrm{~min}^{-1}$ for 6-72 $\mathrm{h}$ with a ball-to-powder weight ratio of $3: 1$. No process-control agent was used. The milling was paused for 5 min after every 40 min to prevent heating. The above $\mathrm{Mg}-\mathrm{Gr}$ powders were loaded into a graphite die with a diameter of $50 \mathrm{~mm}$. A

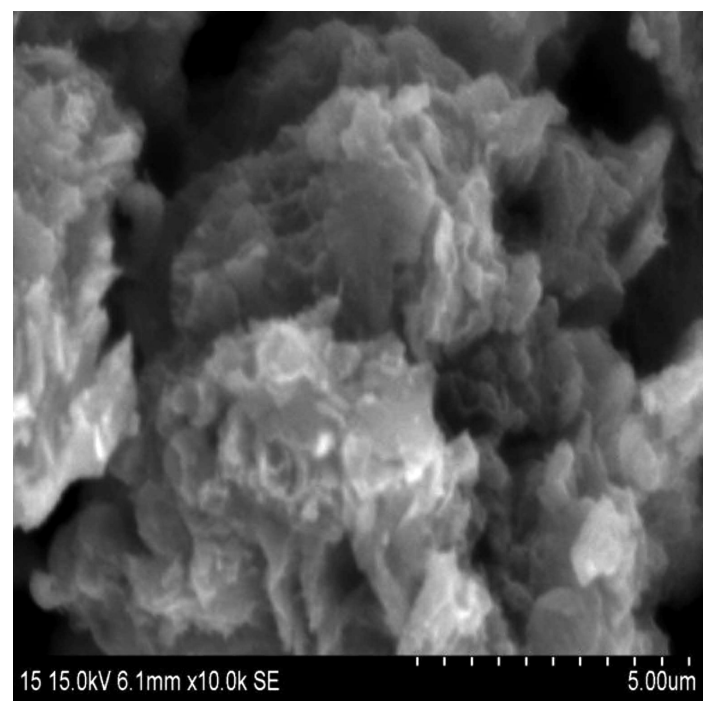

Figure 1: SEM micrograph of graphene nanosheets sheet of graphite paper was placed between the punch and the powders as well as between the die and the powders for easy removal. The compact $\mathrm{Mg}-\mathrm{Gr}$ composite billets were vacuum hot pressed at $610{ }^{\circ} \mathrm{C}$ for $1.5 \mathrm{~h}$ under a pressure of $25 \mathrm{MPa}$ using powder metallurgy. The Mg-Gr composite with $2.0 \%$ mass fraction of graphene nanosheets was rolled at $400{ }^{\circ} \mathrm{C}$ with a thickness reduction of $10 \%$ per pass. The rolling-wheel pressure was $40 \mathrm{t}$, and the rolling-wheel temperature was $25^{\circ} \mathrm{C}$. The as-rolled composites were heat treated at $350{ }^{\circ} \mathrm{C}$ for (1, 2 and 3$) \mathrm{h}$, respectively.

The microstructures of the as-sintered composites were observed with an X-ray diffractometer of Rigaku Ultima IV with $\mathrm{Cu}-K_{\alpha}$ radiation at $40 \mathrm{KV}$ and $40 \mathrm{~mA}$, and a scan rate of $0.02 \%$ in a $2 \theta$ range of $20-90^{\circ}$. The surface morphology was observed with an S-3400N scanning electron microscope (SEM) equipped with an energy-dispersive spectrometer (EDS) and a Carl Zeiss Axioert200MAT optical microscope. The density was measured using Archimedes' method. Theoretical densities of the composites were calculated using rules of mixtures.

\section{RESULTS AND DISCUSSION}

The typical microstructures of the graphene observed with SEM are shown in Figure 1. The graphene nanosheets, having a feather-like, translucent structure, show that their thickness is very thin. The radial size is in the micron order. These nanosheets have the typical characteristics of a folded structure.

The ball-milling time and the graphene content have an important influence over the morphology, powder size, microstructure and physical properties of $\mathrm{Mg}-\mathrm{Gr}$ composites. Figures $\mathbf{2}$ to $\mathbf{4}$ show a comparative analysis for the sintered composites with different milling times and graphene contents. Figure 2 shows the effect of the graphene content (taking $0.5,1$ and $2 \%$ as the examples) on its dispersion for the ball-milling time of $6 \mathrm{~h}$. It can be found that the graphene nanosheets are mainly distributed at the magnesium grain boundaries, showing no obvious agglomeration for the graphene content of $0.5 \%$. However, there is an obvious agglomeration of the graphene nanosheets in the Mg matrix when the content of graphene in the $\mathrm{Mg}-\mathrm{Gr}$ composites is up to $1.0 \%$. This is because magnesium grains cannot be completely coated when the content of graphene is less than $1.0 \%$. The graphene is distributed intermittently at the grain boundaries. When the graphene content is $1.0 \%$, its presence at the grain boundary can be observed (Figure $\mathbf{2 b}$ ); and when the content of graphene is increased, the graphene nanosheets at the magnesium grain boundaries gradually increase. A serious agglomeration of the graphene nanosheets is observed in the Gr composites containing $2.0 \%$ of mass fractions of $\mathrm{Mg}$, as shown in Figure 2c. 

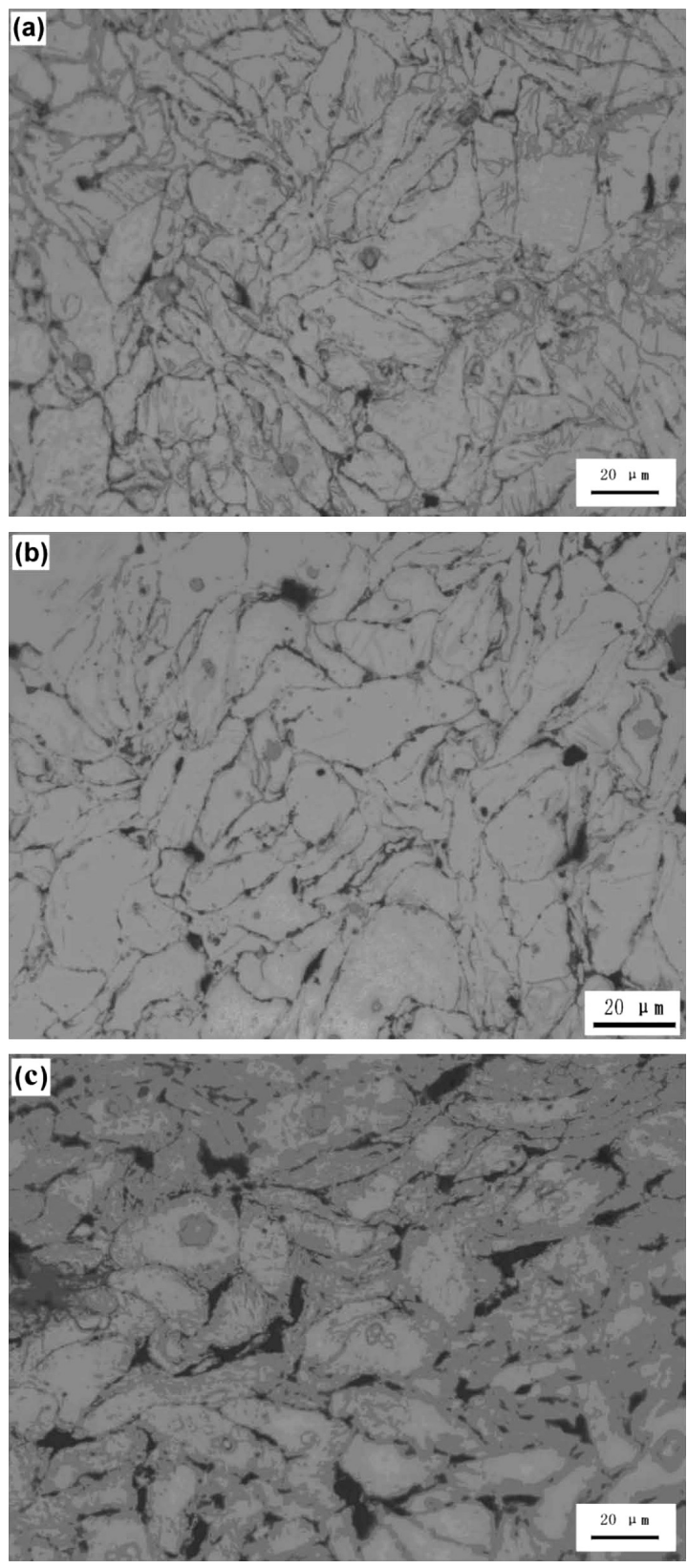

Figure 2: Microstructures of the composites with different graphene contents for the ball-milling time of $6 \mathrm{~h}:$ a) $0.5 \%$, b) $1.0 \%$, c) $2.0 \%$

In order to obtain a uniform dispersion of graphene in the magnesium matrix for a higher content of graphene, the milling time was increased to $72 \mathrm{~h}$. We tried to carry out ball-milling tests at $12 \mathrm{~h}, 24 \mathrm{~h}$ and $48 \mathrm{~h}$, respectively. However, the agglomeration was still present in the composites with $1.0 \%$ graphene. Then the milling time was further extended to $72 \mathrm{~h}$. Figure 3 shows the microstructures of the sintered composites with $1.0 \%$ and $2.0 \%$ graphene contents for the ball-milling time of $72 \mathrm{~h}$. It is found that the graphene nanosheets at the magnesium grain boundaries gradually tend to be uniform for the composites with the $1.0 \%$ graphene content. The figure indicates an excellent dispersion of the graphene in the magnesium matrix after the ball-milling period of $72 \mathrm{~h}$.
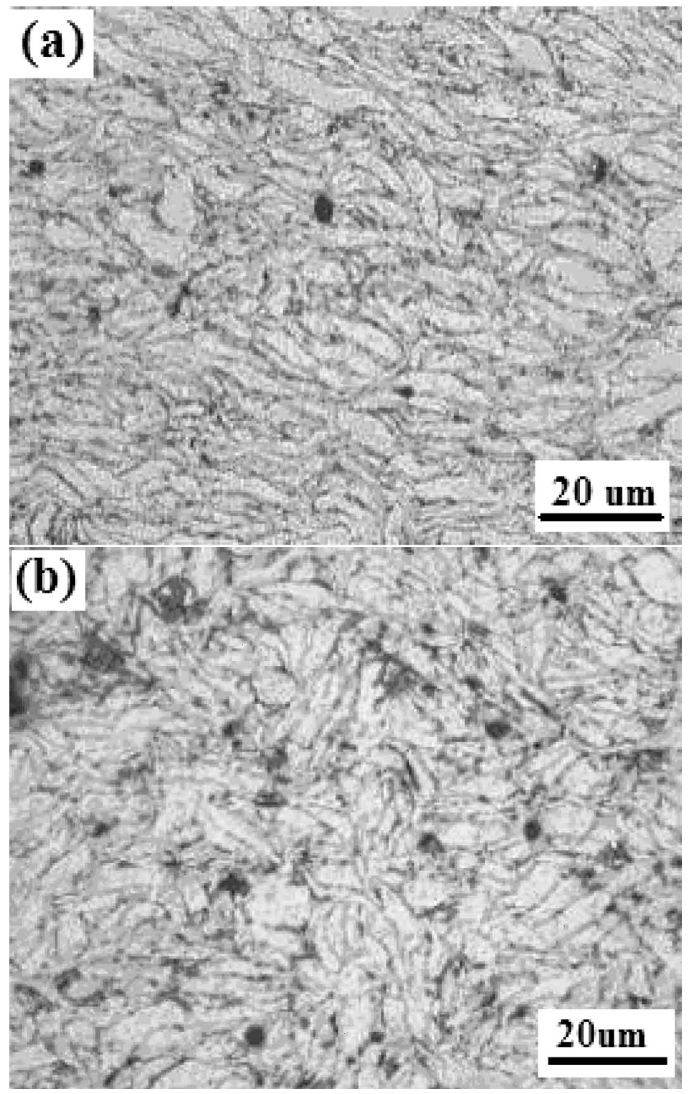

Figure 3: Microstructures of the sintered composites with different graphene contents for the ball-milling time of $72 \mathrm{~h}$ : a) $1.0 \%$ of mass fraction, b) $2.0 \%$ of mass fraction

However, clusters of graphene nanosheets are still visible after $72 \mathrm{~h}$ in the composites with the $2.0 \%$ graphene content (Figure 3b). No experiment with a longer milling time was performed in this study.

In order to eliminate the porosity of the composites, improve the density of the composites and refine the grain size of the composites, hot rolling and heat treatment were successively preformed. Optical micrographs of the $\mathrm{Mg}-\mathrm{Gr}$ composite with the graphene content of $1.0 \%$ in hot-rolling and heat-treatment conditions are presented in Figures $\mathbf{4}$ and $\mathbf{5}$, respectively. It is found that the grains of the as-rolled composite are elongated along the rolling direction, as shown in Figure 4. The graphene nanosheets are still distributed mainly along the grain boundaries. Compared with Figure $\mathbf{2 b}$, it is important to note that a coordinated deformation of the multilayer graphene nanosheets occurs with the deformation of the surface grains, which may cause a significant reduction in the number of layers of the graphene nanosheets. It can be explained that the refinement of the grains on the surface greatly increases the number of grain boundaries, which can cause a reduction of the thickness of the graphene nanosheets. A recovery and recrystallization of the microstructure appear at an aging temperature of $350{ }^{\circ} \mathrm{C}$, as shown in Figure 5. The microstructure of the composite tends toward homogenization 
X. M. DU et al.: SYNTHESIS AND CHARACTERIZATION OF GRAPHENE NANOSHEETS/MAGNESIUM COMPOSITES ...

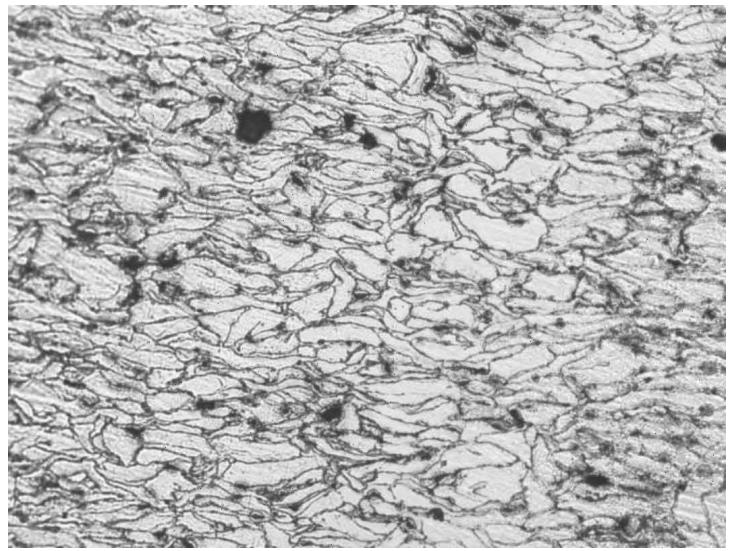

Figure 4: Microstructure of the as-rolled composite with $1.0 \%$ of mass fraction of graphene content

after an aging time of $3 \mathrm{~h}$. This is expected to improve the mechanical properties of the composite. The investigation in this field will be implemented in the future.

The theoretical solid density of magnesium is 1.74 $\mathrm{g} / \mathrm{cm}^{3}$. The density of the sintered sample, $\rho_{\mathrm{ac}}$, was measured using Archimedes' method. The mixture density, $\rho_{\text {th }}$, was calculated with the rule of mixtures, using the theoretical density of $1.74 \mathrm{~g} / \mathrm{cm}^{3}$ for the pure magnesium powder and $2.25 \mathrm{~g} / \mathrm{cm}^{3}$ for the graphene nanosheets, ${ }^{18}$ as follows in Equation (1):

$$
\rho_{\mathrm{th}}=\frac{100}{\frac{W_{\mathrm{mg}}}{\rho_{\mathrm{mg}}}+\frac{W_{\mathrm{g}}}{\rho_{\mathrm{g}}}}
$$

where $\rho_{\mathrm{mg}}$ and $\rho_{\mathrm{g}}$ are the specific weights of the base magnesium powder and graphene nanosheets, respectively; $W_{\mathrm{mg}}$ and $W_{\mathrm{g}}$ indicate the weight percentage of the magnesium powder and graphene nanosheets, respectively. The relative density representing the quality of powder metallurgy, $\phi$, is defined in Equation (2):

$$
\phi=\frac{\rho_{\mathrm{ac}}}{\rho_{\mathrm{th}}} \times 100 \%
$$

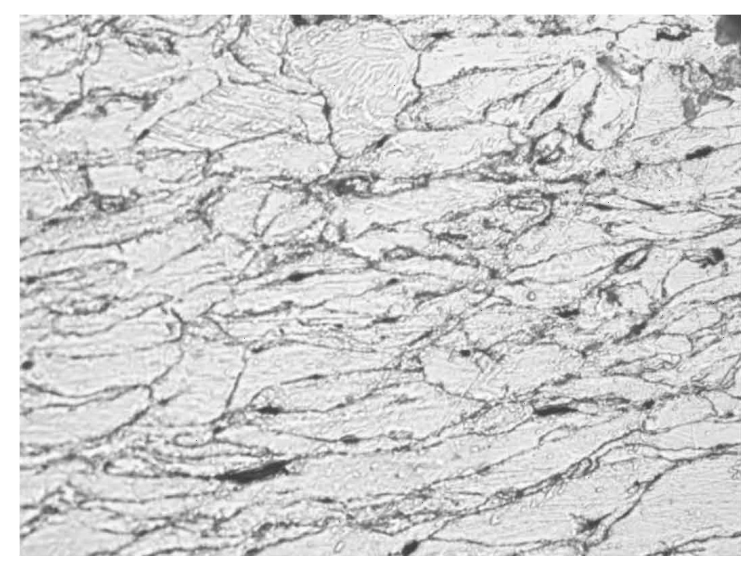

Figure 5: Microstructure of the as-rolled composite with $1.0 \%$ of mass fraction of graphene content after the aging time of $3 \mathrm{~h}$
Based on Equation (1), the densities of the magnesium-based composites reinforced with graphene nanosheets were expected to be increased compared with the density of the pure magnesium powder.

Theoretical, experimental and relative densities of the Mg-Gr composites with different graphene contents are shown in Figure 6. It is found that the relative densities of the composites are more than $99.8 \%$, which shows that the sintered composites are dense. The relative density of the Mg-Gr composites shows a decrease with the increase in the amount of graphene nanosheets in the $\mathrm{Mg}$ matrix (Figure 6a). This may be attributed to the fact that the dispersion of the graphene nanosheets in a $\mathrm{Mg}$ matrix becomes poor and the microvoid increases with the increase in the amount of the graphene nanosheets. The increase in the amount of the graphene nanosheets causes a poor combination of magnesium particles, which results in an increase in the porosity of the composites leading to a poor relative density of the composites. Figure $\mathbf{6 b}$ shows the variation in the theoretical density and experimental density with the variation in the graphene content in the $\mathrm{Mg}-\mathrm{Gr}$ composites. The theoretical density follows the rule of mixture, showing a linear increase with the addition of the graphene nanosheets. However, the experimental density is slightly lower than the theoretical density and the difference bet-
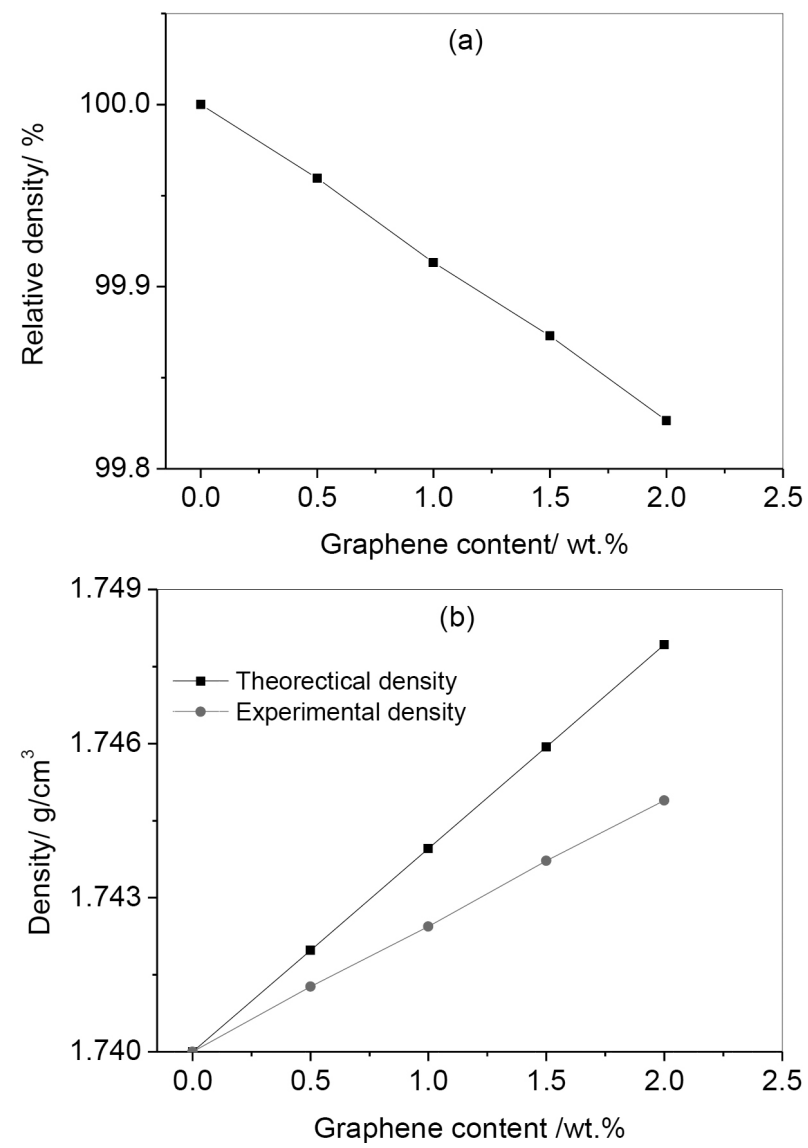

Figure 6: Variation of: a) relative density, b) theoretical density and experimental density of pure $\mathrm{Mg}$ and various $\mathrm{Mg}-\mathrm{Gr}$ composites 


\section{M. DU et al.: SYNTHESIS AND CHARACTERIZATION OF GRAPHENE NANOSHEETS/MAGNESIUM COMPOSITES ...}

ween them becomes large with the increase in the addition of the graphene nanosheets to the Mg matrix. This may lead to a reduction in the mechanical properties.

\section{CONCLUSIONS}

In this work, $\mathrm{Mg}$-Gr composites were fabricated with ball-milling mixing of a pure magnesium powder and graphene nanosheets, followed by hot pressing, rolling and, finally, heat treatment. The contents of the graphene nanosheets were varied from $0.5 \%$ to $2.0 \%$ mass fraction in the magnesium matrix. The microstructures of the as-sintered and as-rolled composites were analyzed; the densities of the $\mathrm{Mg}$-Gr composites in the as-rolled state were tested. Experimental results revealed that the graphene nanosheets were gradually dispersed in the magnesium matrix by increasing the ball-milling time, and a uniform dispersion was achieved after $72 \mathrm{~h}$. No obvious agglomeration of graphene was observed in the as-sintered and as-rolled composites with the contents of the graphene nanosheets of up to $1.0 \%$ mass fraction. A coordinated deformation of the multilayer graphene nanosheets occurs with the deformation of the surface grains during rolling, which may cause a significant reduction in the number of layers of the graphene nanosheets. By increasing the graphene content, the density of the Mg-Gr composites shows an increase.

\section{Acknowledgment}

This work was supported by the Natural Science Foundation of Liaoning (2015602642), Scientific Fund of Liaoning Provincial Education Department and Shenyang Science and Technology Project, Liaoning Province, China.

\section{REFERENCES}

${ }^{1}$ G. Garcés, M. Rodriguez, P. Pérez, P. Adeva, Effect of volume fraction and particle size on the microstructure and plastic deformation of $\mathrm{Mg}-\mathrm{Y}_{2} \mathrm{O}_{3}$ composites, Mater. Sci. Eng., A 419 (2006) 1-2, 357-364, doi:10.1016/j.msea.2006.01.026

${ }^{2}$ B. Nguyen, M. Gupta, Increasing significantly the failure strain and work of fracture of solidification processed AZ31B using nano- $\mathrm{Al}_{2} \mathrm{O}_{3}$ particulates, J. Alloys Compd., 459 (2008) 1-2, 244-250, doi:10.1016/j.jallcom.2007.05.038

${ }^{3}$ G. Huard, R. Angers, M. R. Krishnadev, R. Tremblay, D. Dube, $\mathrm{SiCp} / \mathrm{Mg}$ composites made by low-energy mechanical processing, Can. Metall. Q., 38 (1999) 3, 193-200, doi:10.1179/cmq.1999. 38.3.193
${ }^{4}$ S. F. Hassan, M. Gupta, Development of ductile magnesium composite materials using titanium as reinforcement, J. Alloys Compd., 345 (2002) 1, 246-251, doi:10.1016/S0925-8388(02)00413-9

${ }^{5}$ P. Pérez, G. Garcés, P. Adeva, Mechanical properties of a Mg-10 (vol.\%)Ti composite, Compos. Sci. Technol., 64 (2004) 1, 145-151, doi:10.1016/S0266-3538(03)00215-X

${ }^{6}$ C. S. Goh, J. Wei, L. C. Lee, M. Gupta, Ductility improvement and fatigue studies in Mg-CNT nanocomposites, Compos. Sci. Technol., 68 (2008) 6, 1432-1439, doi:10.1016/j.compscitech.2007.10.057

${ }^{7} \mathrm{~S}$. C. Tjong, Recent progress in the development and properties of novel metal matrix nanocomposites reinforced with carbon nanotubes and graphene nanosheets, Mater. Sci. Eng. R, 74 (2013) 10, 281-350, doi:10.1016/j.mser.2013.08.001

${ }^{8}$ A. A. Balandin, S. Ghosh, W. Bao, I. Calizo, D. Teweldebrhan, F. Miao, C. N. Lau, Superior thermal conductivity of single-layer graphene, Nano Lett., 8 (2008) 3, 902-907, doi:10.1021/n10731872

${ }^{9}$ K. I. Bolotin, K. J. Sikes, Z. Jiang, M. Klima, G. Fudenberg, J. Hone, P. Kim and H. L. Stormer, Ultrahigh electron mobility in suspended graphene, Solid State Commun., 146 (2008) 9-10, 351-355, doi:10.1016/j.ssc.2008.02.024

${ }^{10}$ C. Lee, X. Wei, J. W. Kysar, J. Hone, Measurement of the elastic properties and intrinsic strength of monolayer graphene, Science, 321 (2008), 385-388, doi:10.1126/science.1157996

${ }^{11}$ D. Chen, H. Feng, J. Li, Graphene oxide: preparation, functionalization, and electrochemical applications, Chem. Rev., 112 (2012) 11, 6027-6053, doi:10.1021/cr300115g

${ }^{12}$ J. J. Liang, Y. Huang, L. Zhang, Y. S. Chen, Molecular-Level Dispersion of Graphene into Poly(vinyl alcohol) and Effective Reinforcement of their Nanocomposites, Adv. Funct. Mater., 19 (2009) 14, 2297-2302, doi: 10.1002/adfm.200801776

${ }^{13}$ J. Liu, H. X. Yan, K. Jiang, Mechanical properties of graphene platelet-reinforced alumina ceramic composites, Cerm. Int., 39 (2013) 6, 6215-6221. doi:10.1016/j.ceramint.2013.01.041

${ }^{14}$ M. Rashad, F. Pan, A. Tang, Y. Lu, M. Asif, S. Hussain, J. She, J. Gou, J. Mao, Effect of graphene nanoplatelets (GNPs) addition on strength and ductility of magnesium-titanium alloys, J. Magn. Alloy, 1 (2013) 3, 242-248, doi:10.1016/j.jma.2013.09.004

${ }^{15}$ M. Rashad, F. Pan, J. Zhang, M. Asif, Use of high energy ball milling to study the role of graphene nanoplatelets and carbon nanotubes reinforced magnesium alloy, J. Alloys Compd., 646 (2015) 1, 223-232, doi:10.1016/j.jallcom.2015.06.051

${ }^{16}$ M. Rashad, F. Pan, M. Asif, Exploring mechanical behavior of $\mathrm{Mg}-6 \mathrm{Zn}$ alloy reinforced with graphene nanoplatelets, Mater. Sci. Eng., A 649 (2016) 4, 263-269, doi:10.1016/j.msea.2015.10.009

${ }^{17}$ W. S. Hummers, R. Offeman, Preparation of graphitic oxide, J. Am. Chem. Soc., 80 (1958) 6, 1339-1339, doi: 10.1021/ja01539a017

${ }^{18}$ M. Rashad. F. Pan. A. Tang. M. Asif. J. Gou, Improved strength and ductility of magnesium with addition of aluminum and graphene nanoplatelets (Al+GNPs) using semi powder metallurgy method, Journal of Industrial and Engineering Chemistry, 23 (2015), 243-250, doi:10.1016/j.jiec.2014.08.024 